\title{
Validating prediction equations of metabolizable energy of soybean meal for growing pigs
}

\author{
Validação de equações de predição da energia metabolizável do \\ farelo de soja para suínos em crescimento
}

\author{
Tiago Junior Pasquetti ${ }^{1 *}$; Paulo Cesar Pozza ${ }^{2}$; Newton Tavares Escocard de Oliveira ${ }^{3}$; \\ Ricardo Vianna Nunes ${ }^{3}$; Doglas Batista Lazzeri; Leandro Dalcin Castilha²
}

\begin{abstract}
The aim of this study was to evaluate equations to predict the metabolizable energy (ME) of soybean meal (SBM) for swine. Seven SBM were used, which were analyzed for dry matter, crude protein, ether extract, neutral detergent fiber (NDF), acid detergent fiber (ADF), ash, calcium, phosphorus, solubility in potassium hydroxide $(\mathrm{KOH})$ and urease index. To determine the ME of SBM, 32 barrows, with an average initial weight of $29.01 \pm 3.64 \mathrm{~kg}$, were used and distributed in a randomized blocks design, with seven treatments and four replicates. To validate the prediction equations, linear regression models were adjusted, using observed values of ME (metabolism trial) as a function of the estimated ME (obtained by applying the chemical composition of the SBM in selected equations found in the literature). The existence of regression was evaluated by the "t" test, partially applied to each parameter $\left(\beta_{0}\right.$ and $\left.\beta_{1}\right)$. The validation of the prediction models of first degree was obtained by accepting the joint null hypothesis $\beta_{0}=0$ and $\beta_{1}=1$. The equations $\mathrm{ME}=5.42-17.2 \mathrm{FDN}-19.4 \mathrm{MM}+$ $0.709 \mathrm{GE}$ and $\mathrm{ME}=1099+0.740 \mathrm{GE}-5.5 \mathrm{MM}-3.7 \mathrm{NDF}$ are effective for estimating the ME of SBM for growing pigs.
\end{abstract}

Key words: Chemical composition, linear regression, validation

\section{Resumo}

Objetivou-se com este trabalho avaliar equações para predizer a energia metabolizável (EM) do farelo de soja (FS) para suínos. Foram utilizados sete FS, os quais foram submetidos às análises de matéria seca, proteína bruta, extrato etéreo, fibra em detergente neutro, fibra em detergente ácido, matéria mineral, cálcio, fósforo, solubilidade em hidróxido de potássio $(\mathrm{KOH})$ e índice de urease. Para determinar a EM dos FS foram utilizados 32 suínos, machos castrados, com peso médio inicial de 29,01 $\pm 3,64 \mathrm{~kg}$. O delineamento experimental foi o de blocos ao acaso com sete tratamentos e uma ração referência, sendo utilizadas quatro repetições. Ajustaram-se os modelos de regressão linear utilizando-se valores de EM observados (ensaio de metabolismo) em função da EM estimada (obtidas pela aplicação da composição química dos FS em equações selecionadas na literatura). A existência da regressão foi avaliada pelo teste t parcial aplicado a cada parâmetro $(\beta 0$ e $\beta 1)$. A validação da predição

\footnotetext{
${ }^{1}$ Prof., Dept ${ }^{\mathrm{o}}$ de Zootecnia, Universidade Estadual de Mato Grosso do Sul, UEMS, Aquidauana, MS, Brasil. E-mail: pasquettizoo@ yahoo.com.br

2 Profs., Dept ${ }^{\circ}$ de Zootecnia, Universidade Estadual de Maringá, UEM, Maringá, PR, Brasil. E-mail: pcpozza@yahoo.com.br; leandrocastilha@hotmail.com

${ }^{3}$ Profs., Dept ${ }^{\circ}$ de Zootecnia, Universidade Estadual do Oeste do Paraná, UNIOESTE, Marechal Cândido Rondon, PR, Brasil. E-mail: newtonescocard@hotmail.com; nunesrv@hotmail.com

${ }^{4}$ M.e em Zootecnia, Granja Santista Horn, Marechal Cândido Rondon, PR, Brasil. E-mail: doglaslazzeri@hotmail.com

* Author for correspondence
} 
dos modelos de $1^{\circ}$ grau foi obtida pela aceitação da hipótese de nulidade conjunta $\beta 0=0$ e $\beta 1=1$. As equações $\mathrm{EM}=5,42-17,2 \mathrm{FDN}-19,4 \mathrm{MM}+0,709 \mathrm{~EB}$ e $\mathrm{EM}=1099+0,740 \mathrm{~EB}-5,5 \mathrm{MM}-3,7 \mathrm{FDN}$ são efetivas em estimar a EM do FS para suínos.

Palavras-chave: Composição química, regressão linear, validação

\section{Introduction}

Soybean meal (SBM) has a significant share in diets for pigs and consequently in the production costs; according to Soares Junior et al. (2004), SBM is the second most used component in animal diets, representing about $20 \%$ of all raw materials used. Soybean meal contains $42 \%$ to $48 \%$ of crude protein (CP) and $2 \%$ of oil (ZARDO; LIMA, 1999), showing variability in chemical composition, which consequently leads to variations in metabolizable energy (ME) values.

To determine the nutritional value of feed ingredients for pigs, specific values of digestibility are used, such as digestibility coefficients of CP, gross energy and dry matter, digestible protein, amino acid availability, digestible and ME (PEREIRA et al., 2004). However, NRC (2012) and Rostagno et al. (2011) provide the chemical composition values, digestible and ME, but, according to NRC (1998), the chemical composition may influence the digestible energy, with positive effects on ether extract and negative effects on ash and fiber.

Diet formulation could be based on average values of ME for the feed ingredients found in the literature. However, due to weather conditions, varieties of grains, origin, and storage and processing conditions to which ingredients are exposed, the use of these average values is not recommended. Thus, there is a need to carry out metabolism assays to determine the energetic values and analyze the chemical composition of feed ingredients produced and used in Brazil (SANTOS et al., 2005). Additionally, equations have been suggested to predict, in a faster way, the ME values, requiring lower cost, time and infrastructure compared to the determination through a metabolism assays.

Besides proposing the equations, a subsequent validating study is necessary, because prediction equations often have a good fit for the database in which they were generated, or for the specific situation in which the feed ingredient was produced. In this sense, the objective of this study was to evaluate equations to predict the ME of SBM for growing pigs.

\section{Material and Methods}

The experiment was carried out in the swine metabolism room of the Universidade Estadual do Oeste do Paraná - UNIOESTE. The experimental protocol, number $15 / 10$, was approved by the Universidade Estadual do Oeste do Paraná Ethic Committee (Comitê de Ética na Experimentação Animal and Aulas Práticas - CEEAAP/ UNIOESTE). Thirty two barrows, with an average initial weight of $29.01 \pm 3.64 \mathrm{~kg}$, were distributed in a randomized block design, with seven treatments and four replicates, and were individually allotted to metabolism cages. The experiment consisted of seven days for adaptation to diets and cages, and five days of feces and urine collection, as proposed by Sakomura and Rostagno (2007).

The treatments consisted of seven different batches of SBM, which were analyzed for dry matter (DM), CP, ether extract (EE), neutral detergent fiber (NDF), acid detergent fiber (ADF), mineral matter $(\mathrm{MM})$, calcium $(\mathrm{Ca})$ and phosphorus $(\mathrm{P})$. Each SBM replaced $25 \%$ of the basal diet (Table 1) that was formulated to meet the nutritional requirements of the animals (NRC, 1998). The amount of feed provided per animal was calculated on the basis of metabolic body weight $\left(\mathrm{BW}^{0,75}\right)$. Pigs were daily fed at 07:00 $\mathrm{h}$ and 15:30 $\mathrm{h}$ and the experimental diets were mixed with water $(1: 1 ; \mathrm{w} / \mathrm{v})$ prior to feeding; fresh water was provided ad libitum between meals. 
Feces were collected twice daily, and ferric oxide $\left(\mathrm{Fe}_{2} \mathrm{O}_{3}\right)$ was used $(1.5 \mathrm{~g} / \mathrm{kg}$ diet $)$ in the experimental diets to determine the beginning and end of the feces collection. The collected feces were weighed and stored in a freezer at $-5^{\circ} \mathrm{C}$. At the end of this period, samples were homogenized and dried at $55^{\circ} \mathrm{C}$ for 72 hours to determine gross energy (GE) and DM. Urine was collected individually, once daily, in plastic buckets containing $20 \mathrm{ml}$ of hydrochloric acid (1:1); from the total volume, an aliquot of 5\% was removed and placed in glass vials before being stored $\left(3^{\circ} \mathrm{C}\right)$ for subsequent analyses of GE.

Table 1. Ingredients, chemical and energetic compositions of the basal diet.

\begin{tabular}{|c|c|}
\hline Item & Amount (\%) \\
\hline Corn & 70.10 \\
\hline Soybean meal & 25.56 \\
\hline Dicalcium phosphate & 1.61 \\
\hline Limestone & 0.63 \\
\hline Salt & 0.46 \\
\hline Soybean oil & 0.58 \\
\hline $\mathrm{L}$ - Lysine $\mathrm{HCl}$ & 0.48 \\
\hline L - Threonine & 0.19 \\
\hline DL - Methionine & 0.12 \\
\hline Vitamin premix $^{1}$ & 0.11 \\
\hline Mineral premix ${ }^{2}$ & 0.06 \\
\hline Growth promoter ${ }^{3}$ & 0.10 \\
\hline Antioxidant ${ }^{4}$ & 0.01 \\
\hline \multicolumn{2}{|l|}{ Composition } \\
\hline Metabolizable energy $(\mathrm{kcal} / \mathrm{kg})$ & 3230 \\
\hline Crude Protein (\%) & 18.00 \\
\hline Calcium (\%) & 0.72 \\
\hline Available Phosphorus (\%) & 0.40 \\
\hline Sodium $(\%)$ & 0.20 \\
\hline Digestible lysine (\%) & 1.15 \\
\hline Digestible methionine+cystine (\%) & 0.64 \\
\hline Digestible threonine $(\%)$ & 0.72 \\
\hline
\end{tabular}

${ }^{1}$ Provided per kilogram of product: Iron, $100 \mathrm{~g}$; copper, $10 \mathrm{~g}$; cobalt, $1 \mathrm{~g}$; manganese, $40 \mathrm{~g}$; zinc, $100 \mathrm{~g}$; iodo, 1,5 g; e veículo q.s.p. p/ $1000 \mathrm{~g} ;{ }^{2}$ Content/kg: vit. A, 10.000 .000 U.I.; vit $\mathrm{D}_{3}$, 1.500.000 I.U.; vit. E, 30.000 U.I.; vit $\mathrm{B}_{1}-2,0$ g; vit $\mathrm{B}_{2}-5,0$ g; vit. $\mathrm{B} 6$ - 3,0 g; vit $\mathrm{B}_{12}-30.000 \mathrm{mcg}$; nicotinic acid: 30.000 mcg; pantothenic acid, $12.000 \mathrm{mcg}$; Vit. $\mathrm{K}_{3}, 2.000 \mathrm{mg}$; folic acid, $800 \mathrm{mg}$; biotin, $100 \mathrm{mg}$; selenium: $300 \mathrm{mg}$; and q.s.p qsad vehicle: $1.000 \mathrm{~g} ;{ }^{3}$ Tilosine fosfate $40 ;{ }^{4}$ BHT.
Dry matter analyses of feces and diets were carried out according to the techniques described by Silva and Queiroz (2002), and the GE was determined using an adiabatic calorimeter. The GE digestibility and metabolizability coefficients were determined, as well as digestible energy (DE) and ME values of the different SBM. The digestibility and metabolizability coefficients of GE were submitted to statistical analysis applying the Student Newman Keuls test at 5\% probability, using the software Sistema de Análises Estatítiscas e Genéticas - SAEG (UNIVERSIDADE FEDERAL DE VIÇOSA, 2009).

The chemical composition of the evaluated SBM and those proposed by Rostagno et al. (2011), for the SBM containing 45.22 and $48.10 \%$ $\mathrm{CP}$, were converted into DM basis and used in 24 prediction equations to calculate the estimated metabolizable energy (EME) values of SBM.

The following prediction equations were evaluated: $\mathrm{ME}_{1}=16.13-9.5 \mathrm{NDF}+16 \mathrm{EE}+$ $23 \mathrm{CP} * \mathrm{NDF}-138 \mathrm{MM} * \mathrm{NDF}\left(\mathrm{R}^{2}=0.39\right) ; \mathrm{ME}_{2}=$ $17.50-15.3 \mathrm{NDF}+16 \mathrm{EE}+5.9 \mathrm{CP}-34 \mathrm{MM}\left(\mathrm{R}^{2}=\right.$ $0.40) ; \mathrm{ME}_{3}=18.47-21 \mathrm{NDF}+16 \mathrm{EE}+30 \mathrm{CP} * \mathrm{NDF}-$ $32 \mathrm{MM}\left(\mathrm{R}^{2}=0.40\right) ; \mathrm{ME}_{4}=5.42-17.2 \mathrm{NDF}-19.4 \mathrm{MM}$ $+0.709 \mathrm{GE}\left(\mathrm{R}^{2}=0.43\right) ; \mathrm{ME}_{5}=4334-8.1 \mathrm{MM}+$ 4.1EE - 3.7NDF $\left(\mathrm{R}^{2}=0.91\right) ; \mathrm{ME}_{6}=4194-9.2 \mathrm{MM}+$ $1.0 \mathrm{CP}+4.1 \mathrm{EE}-3.5 \mathrm{NDF}\left(\mathrm{R}^{2}=0.92\right) ; \mathrm{ME}_{7}=4182-$ $9.6 \mathrm{MM}+1.1 \mathrm{CP}+4.1 \mathrm{EE}-2.4 \mathrm{Hemi}-4.4 \mathrm{ADF}\left(\mathrm{R}^{2}=\right.$ $0.93) ; \mathrm{ME}_{8}=1099+0.740 \mathrm{GE}-5.5 \mathrm{MM}-3.7 \mathrm{NDF}$ $\left(\mathrm{R}^{2}=0.85\right) ; \mathrm{ME}_{9}=1.000 \mathrm{DE}-0.68 \mathrm{CP}\left(\mathrm{R}^{2}=0.99\right) ;$ $\mathrm{ME}_{10}=0.997 \mathrm{DE}-0.68 \mathrm{CP}+.023 \mathrm{EE}\left(\mathrm{R}^{2}=0.99\right)$; $\mathrm{ME}_{11}=4369-10.9 \mathrm{MM}+4.1 \mathrm{EE}-6.5 \mathrm{CF}\left(\mathrm{R}^{2}=0.87\right)$; $\mathrm{ME}_{12}=16482-35.7 \mathrm{CF}\left(\mathrm{R}^{2}=0.69\right) ; \mathrm{ME}_{13}=15894+$ $10.3 \mathrm{EE}-35.1 \mathrm{CF}\left(\mathrm{R}^{2}=0.74\right) ; \mathrm{ME}_{14}=15240+3.3 \mathrm{CP}$ $+9.5 \mathrm{EE}-34.9 \mathrm{CF}\left(\mathrm{R}^{2}=0.76\right) ; \mathrm{ME}_{15}=16662-37.5 \mathrm{CF}$ $\left(\mathrm{R}^{2}=0.70\right) ; \mathrm{ME}_{16}=9038-37.3 \mathrm{CF}+0.4 \mathrm{GE}\left(\mathrm{R}^{2}=\right.$ $0.75) ; \mathrm{ME}_{17}=15527-26.0 \mathrm{CF}\left(\mathrm{R}^{2}=0.42\right) ; \mathrm{ME}_{18}=$ 16155 - 30.6CF $\left(\mathrm{R}^{2}=0.76\right) ; \mathrm{ME}_{19}=9141-31.2 \mathrm{CF}+$ $0.4 \mathrm{GE}\left(\mathrm{R}^{2}=0.79\right) ; \mathrm{ME}_{20}=9305-19.7 \mathrm{CF}-5.8 \mathrm{NDF}$ $+0.4 \mathrm{GE}\left(\mathrm{R}^{2}=0.82\right) ; \mathrm{ME}_{21}=15858-28.1 \mathrm{CF}\left(\mathrm{R}^{2}=\right.$ $0.46) ; \mathrm{ME}_{22}=15748-27.6 \mathrm{CF}\left(\mathrm{R}^{2}=0.46\right) ; \mathrm{ME}_{23}=$ 
$4.28+0.19 \mathrm{CP}+0.29 \mathrm{CF}\left(\mathrm{R}^{2}=0.92\right) ; \mathrm{ME}_{24}=8.17+$ $0.17 \mathrm{CP}+0.255 \mathrm{CF}-3.02 \mathrm{P}\left(\mathrm{R}^{2}=0.95\right)$.

The equations ME1 to ME4 were presented by Morgan et al. (1987) to be used to predict the ME for general feed ingredients. The equations ME5 to ME11 were proposed by Noblet and Perez (1993). The equations ME12 to ME22 were proposed by Just et al. (1984) for the prediction of ME for general feeds and equations ME23 and ME24 were proposed by Kang et al. (2004) to be used in the prediction of ME for SBM.

Before carrying out the prediction of the EME, relative to the observed values, the standard deviation (RStudent) was evaluated in order to identify the influential observations or "outliers" that could interfere with the estimates of the $\beta 0$ and $\beta 1$ parameters of the regression. The criteria adopted to identify these "outliers" was based on the normal distribution curve, in which values of RStudent greater than two standard deviations, in absolute values, were considered influents. The predicted values $(\hat{Y})$ of each model of 1 st degree, the real deviation values and the RStudent values were generated using a slash (/) after the MODEL command and including " $p$ " and " $r$ " as options for the REG procedure (SAS, 1999).

The prediction of the observed values of $\mathrm{ME}$ (OME), as a function of EME values, was carried out by adjusting linear regression models of the $1^{\text {st }}$ degree, using the least squares method. The existence of regression, i.e. detection of significance of the estimates of the $\beta 0$ and $\beta 1$ parameters, was verified by partial " $\mathrm{t}$ " test, which was individually applied to each parameter ( $\beta 0$ and $\beta 1$ ). The lack of significance for the angular coefficient of the proposed model indicated that there was no linear relationship between OME and EME, i.e. the values of EME do not explained the variation in OME values.

In cases where the prediction of the 1 st degree model was not significant $(\mathrm{P}>0.05)$ for the intercept, it was removed from the model, and the following model $y i=\beta 1 x i+\varepsilon i$ was adjusted. The analysis was processed again and the null hypothesis tested was restricted to angular coefficient $(\beta 1=0)$.

The validation of the prediction model of $1 \mathrm{st}$ degree, and as a consequence, the validation of the evaluated equations found in the literature as predictors of the linear relationship between ME, from the values of chemical composition, was taken from the adjustment of a linear model of 1st degree predicted values $(\hat{Y})$ as a function of the observed values (Y). The null hypothesis tested (H0) was the joint hypothesis for the parameters of linear regression, where $\beta 0=0$ and $\beta 1=1$.

The validation of the equations was verified when $\mathrm{H}_{0}$ was not rejected when applying the $\mathrm{F}$ test, $\alpha=5 \%$ (MONTGOMERY et al., 2006), indicating the similarity between predicted $(\hat{Y})$ and observed (Y) values, i.e. low magnitude between the residue values $\left(\varepsilon_{\mathrm{i}}=\mathrm{Y}-\hat{\mathrm{Y}}\right)$.

\section{Results and Discussion}

The dry matter content of SBM ranged from 90.26 to $91.03 \%$ (Table 2), while Mendes et al. (2004) found $88.64 \%$ and Veloso et al. (2005) reported a value of $88.08 \%$. 
Table 2. Chemical composition, solubillity in $\mathrm{KOH}$, and urease index for different soybean meals.

\begin{tabular}{lccccccc}
\hline \multirow{2}{*}{ Item } & \multicolumn{7}{c}{ Soybean meal } \\
\cline { 2 - 7 } & 1 & 2 & 3 & 4 & 5 & 6 & 7 \\
\hline Dry matter (\%) & 90.46 & 91.03 & 90.29 & 90.26 & 90.64 & 90.92 & 90.62 \\
$\quad$ (\% as feed) & & & & & & & \\
Crude protein (\%) & 46.00 & 45.65 & 46.09 & 46.14 & 45.02 & 44.66 & 45.24 \\
Ether extract (\%) & 2.42 & 2.12 & 2.16 & 1.65 & 3.18 & 2.27 & 1.92 \\
Neutral detergent fiber (\%) & 15.38 & 14.35 & 13.19 & 16.97 & 17.64 & 13.50 & 16.57 \\
Acid detergent fiber (\%) & 8.97 & 8.00 & 7.82 & 10.02 & 7.53 & 8.17 & 8.57 \\
Crude fiber (\%) & 4.54 & 4.96 & 3.89 & 5.43 & 4.56 & 4.52 & 4.48 \\
Mineral matter (\%) & 6.19 & 5.73 & 6.34 & 5.95 & 5.98 & 6.21 & 5.86 \\
Calcium (\%) & 0.29 & 0.26 & 0.35 & 0.27 & 0.28 & 0.28 & 0.28 \\
$\quad$ Phosphorus (\%) & 0.67 & 0.55 & 0.61 & 0.59 & 0.57 & 0.60 & 0.58 \\
Urease index & 0.04 & 0.03 & 0.03 & 0.04 & 0.02 & 0.03 & 0.03 \\
Solubility in KOH (0,2\%) & 84.68 & 81.71 & 84.45 & 78.32 & 82.86 & 81.75 & 81.50 \\
Gross energy (kcal/kg DM) & 4510 & 4532 & 4765 & 4320 & 4319 & 4248 & 4430 \\
\hline
\end{tabular}

Crude protein values ranged from $44.66 \%$ to $46.14 \%$ (Table 2), and Rostagno et al. (2011) proposed an intermediate value $(45.22 \%)$. This variation between $\mathrm{CP}$ values of SBM is likely to be observed because Butolo (2010) presented six different chemical compositions for SBM and, according to Dilger et al. (2004), soybean hull is one of the factors responsible for the differences between SBM containing $44 \%$ and $48 \% \mathrm{CP}$.

Likewise, EE ranged from 1.65 to $3.18 \%$. Intermediate values of 2.04 and $1.69 \%$ have been presented by Veloso et al. (2005) and Rostagno et al. (2011), respectively. This variation in the content of EE, according to Ost et al. (2005), is influenced by the oil extracting process.

Regarding the NDF, $\mathrm{ADF}$ and $\mathrm{CF}$, variation was also observed between the SBM studied and, according to Rieger et al. (2008), NDF is an estimate of the amount of carbohydrates of low digestibility to non-ruminants, including soybean hull and nonstarch polysaccharides. The fiber content of SBM is influenced by adding lower or higher amounts of soybean hulls, as well as the amount of CP. Veloso et al. (2005) found values of CP that were lower than those obtained in the present study, around $42.44 \%$, and higher values for CF (6.03\%), corroborating the data presented by Ost et al. (2005), who reported that higher soybean hull addition will provide a greater percentage of CF in the SBM. However, in this study, we observed that the SBM with the higher content of CF also presented a higher CP content.

Moreover, the variations observed in the chemical composition of SBM can be attributed to environmental conditions during the production of grains, genetic differences and an interaction between environment and genetics (SAUBER; OWENS, 2001).

The urea activity of SBM (Table 2) ranged from 0.02 to $0.04 \%$, and the solubility in $\mathrm{KOH}$ ranged from 78.32 to $84.68 \%$. Mendes et al. (2004) obtained a urea activity of 0.03 and solubility of $80.22 \%$ in $\mathrm{KOH}$ for SBM. Thus, it can be inferred that the urea activity and solubility in $\mathrm{KOH}$ obtained in this study are within the standards of quality, because the appropriate urea activity ranges from 0.01 to 0.05 , and the solubility in $\mathrm{KOH}$ lies between 75.00 and $85.00 \%$.

The digestibility coefficients of DM (DCDM), CP (DCCP) and GE (DCGE), as well as the metabolizability coefficients of GE (MCGE), were the same $(\mathrm{P}>0.05)$ between the evaluated $\mathrm{SBM}$ (Table 3). 
Table 3. Digestibility coefficients of dry matter (DCDM), crude protein (DCCP), gross energy (DCGE), and metabolizibility coefficients of gross energy (MCGE) of different soybean meals for swine.

\begin{tabular}{lcccccccc}
\hline \multirow{2}{*}{\multicolumn{1}{c}{ Item }} & \multicolumn{7}{c}{ Soybean meals } & \multirow{2}{*}{ CV (\%) } \\
\cline { 2 - 6 } & 1 & 2 & 3 & 4 & 5 & 6 & 7 & - \\
\hline DM (\%) & 90.46 & 91.03 & 90.29 & 90.26 & 90.64 & 90.92 & 90.62 & - \\
DCDM (\%) & 84.88 & 85.21 & 85.60 & 84.89 & 82.55 & 83.78 & 84.40 & 3.72 \\
DIG. DM (\%) & 76.79 & 77.56 & 77.29 & 76.62 & 74.82 & 76.17 & 76.49 & 3.72 \\
CP (\%) & 46.00 & 45.65 & 46.09 & 46.14 & 45.02 & 44.66 & 45.24 & - \\
DCCP (\%) & 91.01 & 89.10 & 90.64 & 88.96 & 90.66 & 89.93 & 91.34 & 3.27 \\
DIG. CP (\%) & 41.86 & 40.68 & 41.77 & 41.05 & 40.81 & 40.16 & 41.32 & 3.27 \\
GE (kcal/kg) & 4080 & 4125 & 4302 & 3899 & 3915 & 3862 & 4014 & - \\
DCGE (\%) & 84.76 & 82.92 & 82.59 & 86.36 & 81.17 & 80.78 & 85.56 & 6.85 \\
DE (kcal/kg) & 3458 & 3421 & 3553 & 3367 & 3178 & 3120 & 3434 & 6.89 \\
MCGE (\%) & 77.91 & 77.70 & 74.36 & 79.15 & 74.34 & 73.29 & 76.86 & 5.49 \\
ME (kcal/kg) & $3179^{\mathrm{a}}$ & $3205^{\mathrm{a}}$ & $3199^{\mathrm{a}}$ & $3086^{\mathrm{ab}}$ & $2910^{\mathrm{ab}}$ & $2830^{\mathrm{b}}$ & $3085^{\mathrm{ab}}$ & 5.50 \\
ME:DE & 0.92 & 0.94 & 0.90 & 0.92 & 0.92 & 0.91 & 0.90 & 5.05 \\
\hline
\end{tabular}

${ }^{1}$ Significant by SNK test $(\mathrm{P}<0.05)$. DIG. DM - digestible dry matter, CP - crude protein, DIG. CP - digestible crude protein, GE gross energy, DE - digestible energy, ME - metabolizable energy, CV - Coefficient of variation.

Digestibility coefficients of DM values ranged from 82.55 to $85.60 \%$ between the different SBM, being lower than those obtained by Veloso et al. (2005). DCCP ranged from 88.96 to $91.34 \%$, while the values proposed by Mendes et al. (2004) and Rostagno et al. (2011) were $90.78 \%$ and $90.00 \%$, respectively.

Gross energy values ranged from 3862 to 4302 $\mathrm{kcal} / \mathrm{kg}$, providing a difference of $440 \mathrm{kcal} / \mathrm{kg}$ of GE, which was greater than the difference presented by Rostagno et al. (2011) for SBM with $45 \%$ and $48 \%$ of $\mathrm{CP}$, in which values of ME were 4090 and $4161 \mathrm{kcal} /$ $\mathrm{kg}$, respectively. Rodrigues et al. (2002) observed a variation from 4029 to $4116 \mathrm{kcal} / \mathrm{kg}$, in which the SBM with higher CP content (46.43\%) and lower CF content $(4.49 \%)$ showed the largest value of GE.

There were no differences $(\mathrm{P}>0.05)$ between the DCGE and, likewise, there were no differences $(\mathrm{P}>0.05)$ between the values of $\mathrm{DE}$ obtained for SBM. The MCGE also presented no differences ( $\mathrm{P}>0.05)$, ranging from $73.29 \%$ to $79.15 \%$, and the value proposed by Rostagno et al. (2011) was intermediate $(77.11 \%)$, while the value found by Veloso et al. (2005) was lower (65.41\%) than those obtained in our study. However, differences were observed $(\mathrm{P}<0.05)$ between the values of $\mathrm{ME}$, which were greater for SBM 1, 2, and 3 compared to SBM 6 (Table 3).

Thus, it can be inferred that the ME values of SBM were mainly influenced by chemical composition, since the SBM were considered appropriate based on $\mathrm{KOH}$ solubility and urease index. In this sense, there is a need to use the chemical composition to accurately predict the ME of SBM prior to formulating diets for pigs.

Among the prediction equations evaluated, five showed a linear relation between OME values and EME values (Table 4), represented by equations $\mathrm{ME}_{4}$, proposed by Morgan et al. (1987), $\mathrm{ME}_{8}, \mathrm{ME}_{9}$ and $\mathrm{ME}_{10}$, presented by Noblet and Perez (1993), and the $\mathrm{ME}_{23}$, proposed by Kang et al. (2004). In adjusting these five models, no differences were observed $(\mathrm{P}>0.05)$ for the intercepts and rejection of the null hypothesis $\mathrm{H}_{0}: \beta_{1}=0$. The mean square error (MSE) is an index that is representative of the accuracy of statistical models. Thus, the equations $\mathrm{ME}_{9}$ and $\mathrm{ME}_{10}$ were the most accurate, because those had the lowest MSE values (Table 4). 
Table 4. Regression equations (E) of the observed values (OME) in function of estimated values (EM) of metabolizable energy of soybean meals, mean square error (MSE), coefficients of determination $\left(\mathrm{R}^{2}\right)$ and $\mathrm{p}$-value of the partial t test for the parameters.

\begin{tabular}{|c|c|c|c|c|c|}
\hline & \multirow{2}{*}{ Estimated regression equations } & \multirow{2}{*}{ MSE } & \multirow{2}{*}{$\mathrm{R}^{2}$} & \multicolumn{2}{|c|}{$P$-value } \\
\hline & & & & $\beta_{0}$ & $\beta_{1}$ \\
\hline $\mathrm{E}_{1}$ & $\mathrm{OME}_{1}=-2054.22490+1.49895 * \mathrm{EME}_{1}$ & 32349 & 0.0491 & 0.8284 & 0.5666 \\
\hline $\mathrm{E}_{2}$ & $\mathrm{OME}_{2}=-678.42194+1.07331 * \mathrm{EME}_{2}$ & 29785 & 0.1245 & 0.8740 & 0.3517 \\
\hline $\mathrm{E}_{3}$ & $\mathrm{OME}_{3}=-6962.55804+2.76362 * \mathrm{EME}_{3}$ & 29241 & 0.1405 & 0.4970 & 0.3203 \\
\hline $\mathrm{E}_{4}$ & $\mathrm{OME}_{4}=0.97584 * \mathrm{EME}_{4}$ & 20295 & - & - & $1.48 * 10^{-12}$ \\
\hline $\mathrm{E}_{5}$ & $\mathrm{OME}_{5}=2690.62429+0.22753 * \mathrm{EME}_{5}$ & 33828 & 0.0056 & 0.4953 & 0.8479 \\
\hline $\mathrm{E}_{6}$ & $\mathrm{OME}_{6}=186.59325+0.90237 * \mathrm{EME}_{6}$ & 31414 & 0.0766 & 0.9663 & 0.4710 \\
\hline $\mathrm{E}_{7}$ & $\mathrm{OME}_{7}=4131.35455-0.19580 * \mathrm{EME}_{7}$ & 33900 & 0.0035 & 0.3817 & 0.8794 \\
\hline $\mathrm{E}_{8}$ & $\mathrm{OME}_{8}=0.98809 * \mathrm{EME}_{8}$ & 19910 & - & - & $1.37 * 10^{-12}$ \\
\hline $\mathrm{E}_{9}$ & $\mathrm{OME}_{9}=1.00734 * \mathrm{EME}_{9}$ & 2192.58834 & - & - & $2.02 * 10^{-16}$ \\
\hline $\mathrm{E}_{10}$ & $\mathrm{OME}_{10}=1.00913 * \mathrm{EME}_{10}$ & 2181.98576 & - & - & $1.98 * 10^{-16}$ \\
\hline $\mathrm{E}_{11}$ & $\mathrm{OME}_{11}=5912.17494-0.72696 * \mathrm{EME}_{11}$ & 32893 & 0.0331 & 0.2809 & 0.6394 \\
\hline $\mathrm{E}_{12}$ & $\mathrm{OME}_{12}=3455.13767-0.00573 * \mathrm{EME}_{12}$ & 34019 & 0.0000 & 0.4916 & 0.9968 \\
\hline $\mathrm{E}_{13}$ & $\mathrm{OME}_{13}=5232.97631-0.52552 * \mathrm{EME}_{13}$ & 33145 & 0.0257 & 0.2512 & 0.6803 \\
\hline $\mathrm{E}_{14}$ & $\mathrm{OME}_{14}=3247.00704+0.05136 * \mathrm{EME}_{14}$ & 34011 & 0.0002 & 0.4974 & 0.9681 \\
\hline $\mathrm{E}_{15}$ & $\mathrm{OME}_{15}=3373.52610+0.01751 * \mathrm{EME}_{15}$ & 34019 & 0.0000 & 0.4838 & 0.9896 \\
\hline $\mathrm{E}_{16}$ & $\mathrm{OME}_{16}=520.31617+0.82927 * \mathrm{EME}_{16}$ & 22526 & 0.3379 & 0.7459 & 0.1007 \\
\hline $\mathrm{E}_{17}$ & $\mathrm{OME}_{17}=3384.80825+0.01484 * \mathrm{EME}_{17}$ & 34019 & 0.0000 & 0.6097 & 0.9939 \\
\hline $\mathrm{E}_{18}$ & $\mathrm{OME}_{18}=3379.27665+0.01604 * \mathrm{EME}_{18}$ & 34019 & 0.0000 & 0.5606 & 0.9922 \\
\hline $\mathrm{E}_{19}$ & $\mathrm{OME}_{19}=155.38370+0.90731 * \mathrm{EME}_{19}$ & 21418 & 0.3704 & 0.9261 & 0.0820 \\
\hline $\mathrm{E}_{20}$ & $\mathrm{OME}_{20}=86.15996+0.93992 * \mathrm{EME}_{20}$ & 20036 & 0.4110 & 0.9563 & 0.0628 \\
\hline $\mathrm{E}_{21}$ & $\mathrm{OME}_{21}=3429.81781+0.00154 * \mathrm{EME}_{21}$ & 34020 & 0.0000 & 0.5842 & 0.9993 \\
\hline $\mathrm{E}_{22}$ & $\mathrm{OME}_{22}=3446.28217-0.00326 * \mathrm{EME}_{22}$ & 34020 & 0.0000 & 0.5866 & 0.9986 \\
\hline $\mathrm{E}_{23}$ & $\mathrm{OME}_{23}=0.93325 * \mathrm{EME}_{23}$ & 18451 & - & - & $1.01 * 10^{-12}$ \\
\hline $\mathrm{E}_{24}$ & $\mathrm{OME}_{24}=690.71899+0.70876 * \mathrm{EME}_{24}$ & 26847 & 0.2109 & 0.7409 & 0.2137 \\
\hline
\end{tabular}

- Indicates rejection of null hypothesis, $\mathrm{H}_{0}: \beta_{1}=0$.

However, when considering the second step of the validation procedure, in which the predicted values of $\mathrm{ME}$, of the five equations, were regressed on their respective energetic values observed for SBM (Table 5), the null hypothesis $\mathrm{H}_{0}: \beta_{1}=1$ was accepted for the models $\mathrm{ME}_{4}, \mathrm{ME}_{9}$ and $\mathrm{ME}_{10}$. These results suggested that the prediction errors of the four regression models were of low magnitude. It should be mentioned that both estimated and predicted values originated from the replacement of chemical composition values of SBM obtained analytically. Thus, the correspondence between OME values in the experiment and those predicted by the models indicates that the models proposed in the literature can be used as a tool to generate estimated values of ME that are close to those obtained in an in vivo study.

For model $\mathrm{ME}_{23}$, a rejection $(\mathrm{P}=0.0006)$ of the joint null hypothesis was observed, $\mathrm{H}_{0}: \beta_{0}=0$ and $\beta_{1}=1$ (Table 5), indicating no statistical similarity between the observed and predicted values of ME. Despite considerable efforts to develop prediction models, Sibbald (1982) reported that not all attempts to relate chemical composition and energy were successful when tested with independent data, 
which confirms the results obtained in the present study, as a small number of prediction equations was satisfactory to predict the values of ME of SBM for pigs when using joint independent data.

Table 5. Regression equations of predicted metabolizable energy (PME) in function of the observed values of metabolizable energy of soybean meal, mean square error (MSE), probability of significance of the partial t test for the parameters, and calculated value of statistical $\mathrm{F}$ and probability of significance for null hypothesis of general linear model.

\begin{tabular}{lccccc}
\hline \multicolumn{1}{c}{ Regression equation } & MSE & \multicolumn{2}{c}{$P$-value } & F & $P$-value \\
\hline $\mathrm{PME}_{4}=0.99847 * \mathrm{OME}_{4}$ & 20264 & - & $1.48^{*} 10^{-12}$ & 0.0122 & 0.9147 \\
$\mathrm{PME}_{8}=0.99850 * \mathrm{OME}_{8}$ & 19881 & - & $1.37 * 10^{-12}$ & 0.0120 & 0.9155 \\
$\mathrm{PME}_{9}=0.99984 * \mathrm{OME}_{9}$ & 2192.22701 & - & $2.02 * 10^{-16}$ & 0.0013 & 0.9719 \\
$\mathrm{PME}_{10}=0.99984 * \mathrm{OME}_{10}$ & 2181.62791 & - & $1.98 * 10^{-16}$ & 0.0013 & 0.9720 \\
$\mathrm{PME}_{23}=2540.29850+0.26076 * \mathrm{OME}_{23}$ & 2494.50341 & 0.0002 & 0.0382 & 26.0862 & 0.0006 \\
\hline
\end{tabular}

- Indicates acceptance of the null hypothesis $\left(\mathrm{H}_{0}: \beta_{1}=1\right)$ to models $\mathrm{ME}_{4}, \mathrm{ME}_{8}, \mathrm{ME}_{9}$ e $\mathrm{ME}_{10}$.

The predicted ME values, when using equations $\mathrm{ME}_{4}, \mathrm{ME}_{8}, \mathrm{ME}_{9}$ and $\mathrm{ME}_{10}$, were similar to those observed in the digestibility assay, but the equations $\mathrm{ME}_{9}$ and $\mathrm{ME}_{10}$ presented lower values for the $\mathrm{F}$ test, as well as higher $p$-values (Table 5), generating a low-residual and providing a better adjustment than equations $\mathrm{ME}_{4}$ and $\mathrm{ME}_{8}$.

Considering the models $\mathrm{ME}_{4}, \mathrm{ME}_{8}$, and $\mathrm{EM}_{9}$ and $\mathrm{EM}_{10}$, the adjustment of predicted values as a function of observed values showed that angular coefficients of both sets of models demonstrated values closed to unity (Fig. 1 and 2), indicating that the lines estimated had a slope that was very close to the line of ideal condition, where the angle with the abscissas axis is $45^{\circ}$; this situation characterizes the similarity between predicted values and observed values. Nevertheless, graphical analysis showed that the pairs of points observed were a little farther from the line estimated by models $\mathrm{EM}_{4}$ and $\mathrm{EM}_{8}$ than for models $\mathrm{EM}_{9}$ and $\mathrm{EM}_{10}$, highlighting the best accuracy for the latter two models to the data of predicted ME (Figures 1 and 2).
The equations $\mathrm{ME}_{4}$ and $\mathrm{ME}_{8}$ that were effective in predicting ME values of SBM are composed of the same predictors (NDF, MM and GE). According to Morgan et al. (1987), the MM had a negative effect on ME, because it acts as a diluent of GE, reducing the organic matter content of the food.

The equations $\mathrm{ME}_{9}$ and $\mathrm{ME}_{10}$ showed the $\mathrm{DE}$ and $\mathrm{CP}$ to be predictors and both can be justified in the same model, because, according to Noblet and Shi (1993), the energy lost in the urine of growing pigs can be described by the equation $\mathrm{E}$. urine $=-16+2.9$ $\mathrm{x}$ digestible $\mathrm{CP}$ (urine energy in $\mathrm{kJ} / \mathrm{kg} \mathrm{DM}$ intake and digestible $\mathrm{CP}$ in $\mathrm{g} / \mathrm{kg} \mathrm{DM}$ intake), which means that each gram of digestible CP consumed above of requirement is deaminated and induces urinary energy loss equivalent to approximately $3 \mathrm{~kJ}$. This energy loss in the urine is a variable percentage of DE, because the urinary energy is highly dependent on the amount of nitrogen in the urine. Equation $\mathrm{ME}_{10}$ shows EE to be a predictor and, also according to Morgan et al. (1987), this predicted variable has a positive effect on ME. 
Figure 1. Regression equations of the predicted metabolizable energy values of soybean meal obtained from the estimated equations $\mathrm{ME}_{4}$ and $\mathrm{ME}_{8}$.

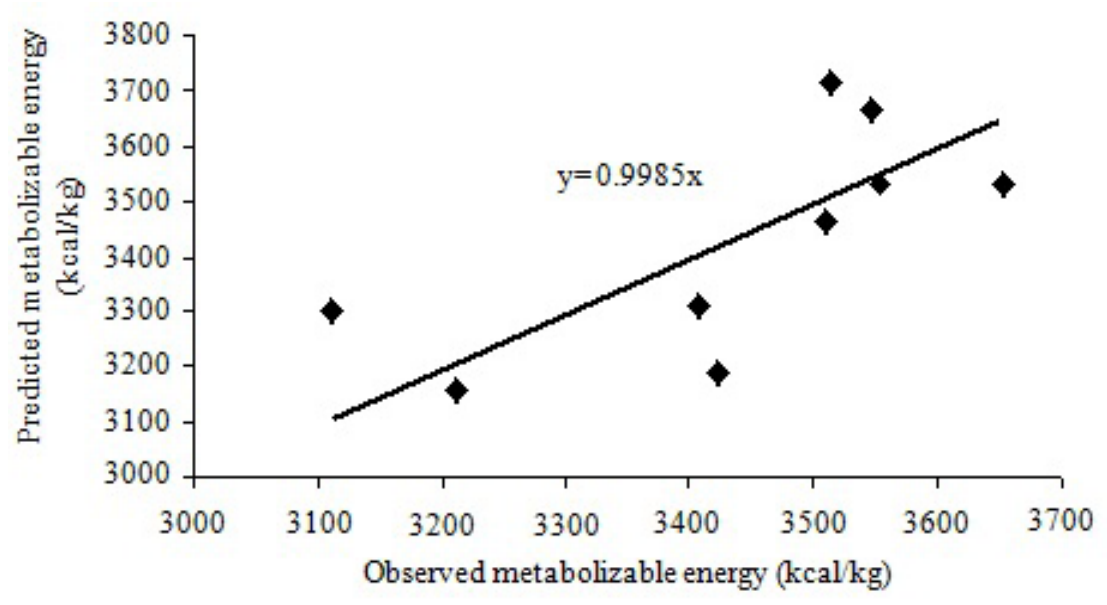

Figure 2. Regression equations of the predicted metabolizable energy values of soybean meal obtained from the estimated equations $\mathrm{ME}_{9}$ and $\mathrm{ME}_{10}$.

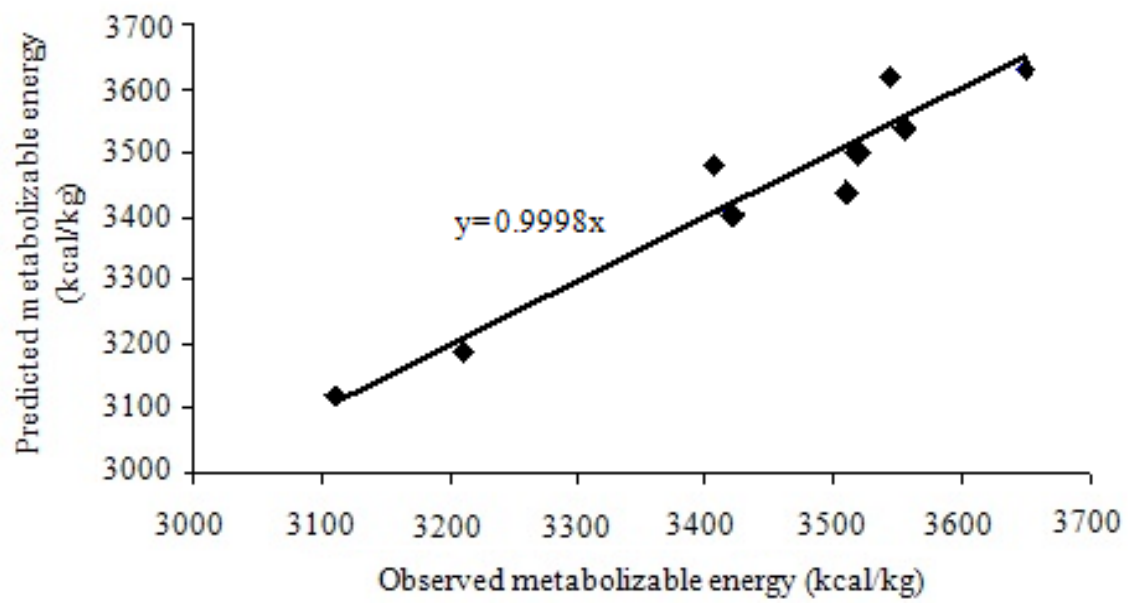

Despite presenting greater accuracy, the Conclusions equations $\mathrm{ME}_{9}$ and $\mathrm{ME}_{10}$ present the $\mathrm{DE}$ as a predictor. However, Pozza et al. (2008) proposed that equations composed of up to four chemical composition variables require less time, have greater ease and save money in the determination of ME. Thus, equations $\mathrm{ME}_{4}$ and $\mathrm{ME}_{8}$ (Table 5) are composed of predicted variables in which laboratory tests are faster in comparison to DE determination, therefore making them easier to use to determine $\mathrm{ME}$ values of soybean meal for pigs.

The prediction equations $\mathrm{ME}=5.42-17.2 \mathrm{NDF}$ $-19.4 \mathrm{MM}+0.709 \mathrm{GE}$ and $\mathrm{ME}=1099+0.740 \mathrm{GE}-$ 5.5MM - 3.7NDF were effective for estimating the ME of soybean meal for swine, being composed of predictors determined only by laboratory analysis.

\section{References}

BUTOLO, J.E. Qualidade de ingredientes na alimentação animal. 2. ed. Campinas: CBNA, 2010. 430 p. 
DILGER, R. N.; SANDS, J. S.; RAGLAND, D.; ADEOLA, O. Digestibility of nitrogen and amino acids in soybean meal with added soyhulls. Journal of Animal Science, Champaign, v. 82, n. 3, p. 715-724, 2004.

JUST, A.; JØRGENSEN, H.; FERNÁNDEZ, J. A. Prediction of metabolizable energy for pigs on the basis of crude nutrients in the feeds. Livestock Production Science, Amsterdam, v. 11, n. 1, p. 105-128, 1984.

KANG, Y.; LI, D.; XING, J. J.; MCKINNON, P. J.; THACKER, P.; SHANG, V. Determination and prediction of digestible and metabolizable energy of dehulled and regular soybean meals for pigs. Journal of Animal and Veterinary Advances, Beijing, v. 3, n. 11, p. 740-748, 2004.

MENDES, W. S.; SILVA, I. J.; FONTES, D. O.; RODRIGES, P. C.; MARINHO, F. O.; AROUCA, C. L. C. Composição química e valor nutritivo da soja crua e submetida a diferentes processamentos térmicos para suínos em crescimento. Arquivos Brasileiros de Medicina Veterinária e Zootecnia, Belo Horizonte, v. 56, n. 2, p. 207-213, 2004.

MONTGOMERY, D. C.; PECK, E. A.; VINING, G. G. Introduction to linear regression analysis. $4^{\text {th }}$ ed. New Jersey: John Wiley\& Sons, Inc., 2006. 612 p.

MORGAN, C. A.; WHITTEMORE, C. T.; PHILLIPS, P.; CROOKS, P. The prediction of the energy value of compounded pig foods from chemical analysis. Animal Feed Science Technology, Amsterdam, v. 17, n. 2, p. 81107, 1987.

NATIONAL RESEARCH COUNCIL - NRC. Nutrient requirements of swine: eleventh revised edition. Washington, DC: The National Academies Press, 2012. $400 \mathrm{p}$.

Nutrients requirement of swine. $10^{\text {th }} \mathrm{ed}$. Washington D.C: National Academic Press, 1998, 189 p.

NOBLET, J.; PEREZ, J. M. Prediction of digestibility of nutrients and energy values of pig diets from chemical analysis. Journal of Animal Science, Champaign, v. 71, n. 12, p. 3389-3398, 1993.

NOBLET, J.; SHI, X. S. Comparative digestibility of energy and nutrients in growing pigs fed ad libitum and adult sows fed at maintenance. Livestock Production Science, Los Angeles, v. 34, n. 1-2, p. 137-152, 1993.

OST, R. P.; RODRIGUES, P. B.; FIALHO, E. T.; FREIN, R. T. F.; BERTECHINI, A. G. Valores energéticos de sojas integrais e de farelos de soja determinados com galos adultos e por equações de predição. Ciência $e$ Agrotecnologia, Lavras, v. 29, n. 2, p. 467-475, mar./abr. 2005.
PEREIRA, L. E. J.; FERREIRA, A. S.; SILVA, F. C. O.; DONZELlE, J. L.; VIEIRA, M. L.; ALBINO, L. F. T. Digestibilidade de alimentos proteicos para suínos com diferentes dietas-referência. Boletim da Indústria Animal, Nova Odessa, v. 61, n. 1, p. 75-81, 2004.

POZZA, P. C.; GOMES, P. C.; DONZELE, J. L.; ROSTAGNO, H. S.; POZZA, M. S. S.; NUNES, R. V. Composição química, digestibilidade e predição dos valores energéticos da farinha de carne e ossos para suínos. Acta Scientiarum Animal Science, Maringá, v. 30, n. 1, p. 33-40, 2008.

RIEGER, C.; OLIVEIRA, V.; LOVATTO, P. A.; ARAÚJO, J. S.; PEIXOTO, E. C. T. M.; SILVA, M. A. Características químicas e valores energéticos de farelos de soja do Oeste e Sudoeste do Paraná. Ciência Rural, Santa Maria, v. 38, n. 1, p. 266-269, jan./fev. 2008.

RODRIGUES, P. B.; ROSTAGNO, H. S.; ALBINO, L. F. T.; GOMES, P. C.; NUNES, R. V.; TOLEDO, R. $\mathrm{S}$. Valores energéticos da soja e subprodutos da soja, determinados com frangos de corte e galos adultos. Revista Brasileira de Zootecnia, Viçosa, MG, v. 31, n. 4, p. 1771-1782, 2002.

ROSTAGNO, H. S.; ALBINO, L. F. T.; DONZELE, J. L.; GOMES, P. C.; OLIVEIRA, R. F.; LOPES, D. C.; FERREIRA, A. S.; BARRETO, S. L. T.; EUCLIDES, R. F. Tabelas brasileiras para aves e suínos: composição de alimentos e exigências nutricionais. 3. ed. Viçosa: UFV, 2011. 252 p.

SAKOMURA, N. K.; ROSTAGNO, H. S. Métodos de pesquisa em nutrição de monogástricos. Editora: FUNEP, Jaboticabal, 2007. 283 p.

SANTOS, Z. A. S.; FREITAS, R. T. F.; FIALHO, E. T.; RODRIGUES, P. B.; LIMA, J. A. F.; CARELLOS, D. C.; BRANCO, P.A.C.; CANTARELLI, V.S. Valor nutricional de alimentos para suínos determinado na Universidade Federal de Lavras. Ciência e Agrotecnologia, Lavras, v. 29, n. 1, p. 232-237, jan./fev. 2005.

STATISTICAL ANALYSIS SYSTEM INSTITUTE SAS. SAS INSTITUTE, SAS/STAT users guide. Version 6. 12. Cary, NC: Editora: North Carolina State University, 1999. $3700 \mathrm{p}$.

SAUBER, T. E; OWENS, F. N. Cereal grains and byproducts for swine. In: LEWIS, A.; SOUTHERN, L. L. (Ed.). Swine nutrition. $2^{\text {th }}$ ed. Washington, D.C., CRC Press, 2001. p. 785-802.

SIBBALD, I. R. Measurement of bioavailable energy in poultry feedingstuffs: a review. Canadian Journal of Animal Science, Sherbrooke, v. 62, n. 4, p. 983-1048, 1982. 
SILVA, D. J.; QUEIROZ, A. C. Análise de alimentos: métodos químicos e biológicos. 3. ed. Viçosa: Ed. UFV, 2002. $235 \mathrm{p}$.

SOARES JUNIOR, M. S.; CALIARI, M.; CHANG, Y. K. Substituição de farelo de soja por soja integral em rações extrusadas para aquicultura. Pesquisa Agropecuária Tropical, Goiânia, v. 34, n. 1, p. 29-37, 2004.

UNIVERSIDADE FEDERAL DE VIÇOSA - UFV. CPD. SAEG - Sistema para análise estatística e genética. Versão 5. 0. Viçosa, MG: Editora: Universidade Federal de Viçosa, 2009. 59 p.
VELOSO, J. A. F.; MEDEIROS, S. L. S.; AROUCA, C. L. C.; RODRIGUEZ, N. M.; SALIBA, E. O. S.; OLIVEIRA, S. G. Composição química, avaliação físicoquímica e nutricional e efeito da expansão do milho e do farelo de soja para suínos em crescimento. Arquivos Brasileiros de Medicina Veterinária e Zootecnia, Belo Horizonte, v. 57, n. 5, p. 623-633, 2005.

ZARDO, A. O.; LIMA, G. J. M. M. Alimentos para suínos. Boletim Informativo BIPERS, Concórdia, v. 8, n. 12, p. 7-61, 1999. Disponível em: <http:// file.aviculturaindustrial.com.br/Material/Tecnico/ alimentosuino.pdf>. Acesso em: 21 maio 2014. 
